\title{
THE EFFECT OF IMPLEMENTATION OF POLICY AND COORDINATION ON THE QUALITY OF SERVICE IN THE CAPITAL INVESTMENT AND INTEGRATED SERVICES OF THE SPECIAL PROVINCE OF THE JAKARTA CAPITAL PROVINCE
}

\author{
Hadi Makayasa Sembiring \\ Postgraduate Program Student, Master of Management Study Program \\ Satyagama University Jakarta, Indonesia \\ Dr. Rahimullah, SH, M.Si \\ Chairman of the Supervising Team, Master of Management Study Program \\ Satyagama University Jakarta, Indonesia \\ Dr. Ir. Sriyono Joko Sutopo, MS \\ Members of Supervising Team, Master of Management Study Program \\ Satyagama University Jakarta, Indonesia \\ DOI: 10.31364/SCIRJ/v8.i1.2020.P0120739 \\ http://dx.doi.org/10.31364/SCIRJ/v8.i1.2020.P0120739
}

\begin{abstract}
The current condition of public service delivery is still inadequate, because there are still many complaints and complaints from the public both directly and through the mass media, such as convoluted procedures, there is no certainty over the completion period, it is unclear how much the cost must be incurred, the requirements non-transparent attitude of officers who are not good, resulting in decreased quality of service to the community. These problems arise partly because of weak policy implementation and coordination. This study aims to analyze the Effect of Policy Implementation and Coordination on Service Quality in the Investment Service and Integrated Services of the One Door Province of the Special Capital Region of Jakarta. Research on the Influence of Policy Implementation and Coordination on Service Quality at the Investment Service and Integrated Services of One Door Province of the Special Capital Region of Jakarta uses quantitative methods with explanatory research types, with research respondents totaling 150 people determined by the Slovin formula. Data collection techniques in this study are the techniques of documentation, questionnaires and literature. Data collection tool in the study of the Effect of Policy Implementation and Coordination Against Service Quality in the Office of Investment and Integrated Services of One Door Province of the Special Capital Region of Jakarta. this is a list of statements using the Liekert scale. Based on the results of the study it was concluded that there was an effect of policy implementation on service quality by $51.3 \%$ and the effect of coordination on service quality by $52.1 \%$ and together the effect of policy implementation and coordination on service quality at the Office of Investment and One Stop Integrated Services The Province of the Special Capital Region of Jakarta is $67.4 \%$ which means it must be considered so that the quality of services in the Investment Office and the One Stop Integrated Service of the Province of the Special Capital Region of Jakarta in the future are better.
\end{abstract}

Index Term : policy implementation, coordination, service quality.

\section{BACKGROUND}

DKI Jakarta Province as an international representation of Indonesia should be able to learn from good practices carried out, this province has all the conditions and facilities support to be able to provide better licensing services than other regions. However, in reality, there are still people who consider that the management of permits in Jakarta is very difficult because of the community's lack of understanding of the mechanism for obtaining permits either regarding the length of time and requirements that must be met in the management of permits in DKI Jakarta, specifically permits to start a business. The community considers that there are still many convoluted bureaucratic chains. Responding to the opinion of a handful of people, the Regional Government and the DKI Jakarta Regional House of Representatives (DPRD) began to work on improving the existing conditions. In the current policy, on 11 December 2013, the Regional Government and the Regional Representative Council approved the Regional Regulation on the implementation of PTSP which was then recorded in the Regional Gazette as Regional Regulation No. 12 of 2013. The public should welcome the important initiative in the form of the birth of the main regulation. the issuance of Perda No. 12 of 2013 is the first step in the effort to reform the licensing bureaucracy in Jakarta. in general, the local regulation contains a number of info clauses from the One Stop Integrated Service (PTSP), a matter of authority, organizational structure, Human Resources (HR), information technology and finance. of course, these various clauses still need to be elaborated at the 
level of policy instruments through the creation of a number of derivative regulations and operational preparations for business processes or licensing.

Facing an era of globalization which is full of challenges and opportunities, the government should be able to provide the best service, oriented to the needs and satisfaction of service recipients so that it can improve competitiveness in the delivery of public services. Generally in Indonesia, public services provided by the public sector are worse than services provided by the private sector. Public services in Indonesia are still characterized by services that are difficult to access, convoluted procedures when having to take care of a particular permit, unclear costs and the occurrence of gratification practices, this is an indicator of the low quality of public services in Indonesia.

Licensing is a matter that has been complained of by the public, as well as investors, aside from the considerable time that is also unclear costs, as well as doubts about guaranteed investment security. Meanwhile, investment is very important in the midst of government limitations in financing all types of development needs, so that the government can stimulate private sector participation to succeed the national development program. Foreign investment and domestic investment are really needed by the Indonesian people for the progress of the Indonesian State. Interest from investors is largely determined by the investment climate of a country. One of the factors used by the meters to assess whether a place to invest is conducive or not, namely the existence of legal certainty, meaning that whether the investment / investor in investing is guaranteed by clear laws and regulations. Therefore, the challenge facing Indonesia is how to create a conducive, competitive investment climate to be able to compete with other countries that are also trying to attract investors into their country.

Improving the regional investment climate is a necessity for improving national investment performance. The Jakarta Capital City Integrated Investment and One Stop Services Office in an effort to improve public services, especially in the field of investment licensing, and in an effort to make the regional investment climate more conducive, also participated in implementing the Electronic Investment Licensing and Information Services System (SPIPISE). conduct licensing in a simple, inexpensive, efficient and predictable manner. SPIPISE is also an information system developed to provide convenience, create transparency and legal certainty for investors.

Based on the explanation above and to follow up on the existing problems, the writer feels interested to do research with title "The Effect of Policy Implementation and Coordination on Service Quality in the Office of Investment and Integrated Services of One Door Province of the Special Capital Region of Jakarta".

The objectives in this study are:

1. To find out and analyze the magnitude of the effect of policy implementation on service quality at the Investment Service and Integrated Services of the One Door Province of the Special Capital Region of Jakarta.

2. To find out and analyze the magnitude of the influence of Coordination on the quality of services in the Office of Investment and Integrated Services One Door Province of the Special Capital Region of Jakarta.
3. To find out and analyze the magnitude of the influence of the implementation of policies and the process of coordiation together on the quality of services in the Office of Investment and Integrated Services of One Door Province of the Special Capital Region of Jakarta.

While the uses of this research are:

\section{Theoretical use}

a. To develop the knowledge being studied specifically about the effect of policy implementation and coordination on service quality.

b. As a reference material conduct research with the same topic or research title.

\section{Practical use}

a. As scientific input for the Investment and Integrated Services Office of the One Door Province of the Special Capital Region of Jakarta to be able to take the implementation of policies in order to improve service quality.

b. It is expected to be used as a benchmark for the Office of Investment and Integrated Services of the One Door Province of the Special Capital Region of Jakarta regarding Service Quality.

\section{LITERATURE REVIEW}

\section{Implementation of Policies in improving Service Quality}

The implementation of the policy includes a number of efforts made by DPMPTSP both in terms of programs and human resources in realizing the objectives of a policy formulated to provide the best service to the community as a policy assessor. Van Meter and Horn Wahab (2010:65), defines policy implementation as actions taken by individuals / officials or groups of government or private that are directed at the achievement of the objectives outlined in decisions and policies.

\section{Coordination in improving Service Quality}

Coordination is also an effort in order to improve the quality of services to the community including service users because they can communicate directly with DPMPTSP employees to provide positive criticism and suggestions that will make the organization better. Other than that it does Intensive coordination between relevant regional apparatus organizations as well as officials who are directly involved in the practice of providing services in the form of licenses is also an important thing in improving service quality. By coordinating the exchange of opinions it can be seen things that do not yet exist or things that must be improved and find new ideas that can improve the quality of service.

According to Ismail Solihin (2009:91), the first characteristic of an organization is the coordination of efforts from the human resources involved in the organization. A well-coordinated merger will produce something far better than individual efforts.

\section{Implementing Policies and Coordination Together in improving Service Quality}


Triguno (2000:76) defines service quality as a standard that must be achieved by a person / group/ institution / organization regarding the quality of human resources, the quality of work methods, processes and results of work or products in the form of goods and services. Quality has a meaning satisfying to those served, both internal and external, in the sense of optimal fulfillment of the demands / requirements of public customers. Quality is basically related to the best service, which is the attitude of the service provided quickly and satisfactorily, being polite, friendly and helpful, as well as professional and competent.

Service quality is the level of success in carrying out service tasks between the Investment Office and the OneStop Integrated Service to the community as an appraiser of services, both good and bad of a service quality is determined by several supporting factors including the implementation of policies and coordination which are important in improving service quality at the DKI Jakarta Provincial Investment and One Stop Integrated Services Office.

\section{RESEARCH METHOD}

In this study, researchers used a quantitative approach that basically uses deductive, and exploratory nature using quantitative data in the form of numbers or qualitative data that is being framed. Thus the data obtained are complementary and integrated with each other, so that they can be accounted for and can solve problems.

Accordingly, the authors examine the interaction relationship between three independent variables (independent variables) consisting of policy implementation as a factor $\mathrm{X}^{1}$ and Coordination as $\mathrm{X}^{2}$ while the dependent variable (the dependent variable) is Service quality as a $\mathrm{Y}$ factor, in addition there are other factors influential called Epsilon.

The data collection techniques used by the authors in collecting data for the preparation of this study are the Field Research Techniques, carried out by going directly to the field (survey) using a questionnaire data collection tool, which is a data collection technique by presenting questions in writing to respondents, the questionnaire is cooperative, it is expected that cooperation in setting aside time and answering questions in writing according to the instructions given by the author.

Besides that we also do Library Research Techniques, this research technique is carried out to support theoretical or conceptual ideas about research variables, which in this case are supported by collecting data from text books or literature and documents or in the form of archives events / events from various activities that can be used as material for study in this study.

The location of this study in the Office of Investment and Integrated Services One Door Province of the Special Capital Region of Jakarta. The sample in this study was the Community as Permit Applicants and Civil Servants in the Field of Environmental Assessment and Development in the Office of Investment and Integrated Services of One Door Province of the Special Capital Region of Jakarta as many as 150 people

\section{RESEARCH RESULTS AND DISCUSSION}

Testing Requirements Analysis
Test requirements analysis in research The Influence of Policy Implementation and Coordination on Service Quality in the Investment Office and Integrated Services of One Door Province of the Special Capital Region of Jakarta is the test of data instruments in the form of validity and reliability tests. For each test described as follows :

\section{A. Test Validity}

Validity test is done to determine the validity level of the instruments (questionnaires) used in data collection. The validity requirement of the instrument (questionnaire) is the value of $r$ count $>r$ table. Based on the results of the analysis with the correlation technique "product moment" obtained $r$ count for each variable as follows:

\section{a. Policy Implementation Variable $\left(\mathrm{X}^{\mathbf{1}}\right)$}

From the calculation results it is known that the r-count value of the policy implementation variable obtained is apparently greater than r-table $(0.159)$ or $r$-count> rtable and all 15 research instrument data items are said to be valid. The dominant indicators are operational actions, target objectives, public organizations, and the implementation process.

b. Coordination Variable $\left(\mathbf{X}^{\mathbf{2}}\right)$

From the calculation results it is known that the r-count value of the coordination variable obtained turns out to be greater than r-table $(0.159)$ or r-count $>$ r-table and all 15 research instrument data items are said to be valid, with the dominant indicator being social relations, responses, attitudes, environment, and attitude changes.

\section{c. Service Quality Variable (Y)}

From the calculation results it is known that the r-count value of the obtained service quality variable is apparently greater than r-table $(0.159)$ or r-count> rtable and all 15 research instrument data items are said to be valid, with the dominant indicator being simple, conditional, efficient, conditional, and adaptive.

\section{B. Reliability Test}

Reliability tests are carried out to determine whether the instrument is used more than once, will produce consistent data. In this study, the reliability test was carried out using the Alpha Cronbach technique. The instrument is declared reliable if the Cronbach Alpha value> 0.6.

Table 1. Reliability Test Results

\begin{tabular}{|l|l|l|l|}
\hline No & \multicolumn{1}{|c|}{ Variabel } & $\begin{array}{c}\text { Alpha } \\
\text { Cronbach }\end{array}$ & Keterangan \\
\hline 1 & $\begin{array}{l}\text { Implementasi Kebijakan } \\
\left(\mathrm{X}^{1}\right)\end{array}$ & 0.973 & \multirow{2}{*}{ Reliabel } \\
\hline 2 & Koordinasi $\left(\mathrm{X}^{2}\right)$ & 0.965 & \\
\hline 3 & Kualitas Pelayanan (Y) & 0.855 & \\
\hline
\end{tabular}

Source: SPSS 17 for windows

Based on the results of testing the reliability of the instrument shows that the instrument used is reliable which means the instrument can be trusted enough to be used as a data collection tool.

\section{Classical Assumptions}


The classical assumptions tested consisted of three tests, including the normality test, the multicollinearity test, and the heteroscedasticity test.

\section{a. Normality test}

Normality test to find out whether the dependent variable, independent or both are normally distributed, close to normal or not. Detect a data with normal distribution or cannot be known through statistical analysis. To be able to see whether the multiple regression model has a normal distribution or not the $\mathrm{P}$ $\mathrm{P}$ plot graph is used. The following is the result of normality test data using the P-P plot graph.

\section{b. Heteroscedasticity Test}

Heteroscedasticity test is performed to determine whether in a regression model there is an inequality of variance from the residuals of the observations to other observations. Estimation results using SPSS program application assistance are presented through the Spearman rank test in which the independent variables are correlated with the absolute standardized residual data at the significance level $(\alpha)$ of 0.05 . If the significance value of each independent variable is greater than 0.05 , it shows that the data has fulfilled the homoscedasticity assumption.

Table 2. Probability Value of Spearman Rank Heteroscedasticity Test

\begin{tabular}{|c|c|c|c|}
\hline \multicolumn{4}{|c|}{ Correlations } \\
\hline & & & Abs Res 1 \\
\hline \multirow[t]{6}{*}{ Speaman's rho } & \multirow{3}{*}{$\begin{array}{l}\text { Implementasi } \\
\text { Kebijakan (X1) }\end{array}$} & Correlation Coefficient & -.075 \\
\hline & & Sig. (2-tailed) & .362 \\
\hline & & $\mathrm{N}$ & 150 \\
\hline & \multirow[t]{3}{*}{ Koordinasi (X2) } & Correlation Coefficient & -.153 \\
\hline & & Sig. (2-tailed) & .062 \\
\hline & & $\mathrm{N}$ & 150 \\
\hline
\end{tabular}

Based on the above table, it can be seen that the magnitude of the probability value of each independent variable is Policy Implementation $\left(\mathrm{X}^{1}\right)=0.362$ and Coordination $\left(\mathrm{X}^{2}\right)=0.062$. Because the probability of the estimated results of each independent variable is greater than the real significance level determined (0.05), it can be concluded that the data has fulfilled the assumption of homoscedasticity.

\section{c. Multicollinearity Test}

The multicollinearity test aims to evaluate the presence or absence of strong correlations between independent variables, where there is a strong correlation between independent variables indicating that the use of independent variables in the regression model is inefficient. By using the SPSS program application, it is obtained the estimated results of the VIF value of each independent variable for the multicollinearity test as follows:

Table 3. VIF Value of Multicollinearity Test

\section{Coefficients $^{\mathrm{a}}$}

\begin{tabular}{|ll|r|c|}
\hline \multirow{2}{*}{ Model } & \multicolumn{2}{|c|}{ Collinearity Statistics } \\
\cline { 3 - 4 } & \multicolumn{1}{|c|}{ Tolerance } & \multicolumn{1}{c|}{ VIF } \\
\hline 1 & Implementasi & .717 & 1.395 \\
& Kebijakan $(\mathrm{X} 1)$ & .717 & 1.395 \\
\hline
\end{tabular}

a. Dependent Variable: Kualitas Pelayanan (Y)

The estimation results of the VIF value presented through the table above show that the VIF value of each independent variable is below the critical value of 10, namely Policy Implementation $\left(\mathrm{X}^{1}\right)=1.395$ and Coordination $\left(\mathrm{X}^{2}\right)=1.395$. Based on these results, it can be concluded that there is no multicollinearity between independent variables in the regression model.

\section{Hypothesis Testing}

Hypothesis testing conducted in this study is by two-sided or two-sided test techniques. Then based on the results of testing the three hypotheses obtained test results that can be explained as follows:

\section{a). First Hypothesis Testing}

H0: $\beta 1=0$ : there is no effect of policy implementation on service quality.

Ha: $\beta 1 \neq 0$ : there is a positive effect of policy implementation on service quality.

If $\mathrm{t}>\mathrm{t}$ table, then $\mathrm{H} 0$ is rejected and $\mathrm{Ha}$ is accepted.

\section{a. T test}

Based on the results of the calculation of SPSS (Statistical Product and Service Solution) 17 for Window, the tcount obtained was 12,479 and the table with df 148 at $\alpha(0.05)$ was 1,976 . Therefore tcount 12.479> t table 1,976 so that $\mathrm{H} 0$ is rejected and $\mathrm{Ha}$ is accepted. This shows that policy implementation has a significant influence on service quality.

\section{b. Determination Analysis}

Based on the analysis obtained a coefficient of determination of 0.513 . This shows that $51.3 \%$ of the diversity of policy implementation is due to the diversity of service quality, while the remaining $48.7 \%$ is caused by other variables.

c. Simple Linear Regression Equation

Based on the analysis obtained simple linear regression equation values as follows:

- $\hat{\mathrm{Y}}=\mathrm{a}+\mathrm{b} 1 \mathrm{X} 1$

$-\hat{\mathrm{Y}}=0.907+0.425 \mathrm{X} 1$

This linear regression equation shows that every increase of 1 value of the policy implementation variable can increase the value of service quality by 1.332 with the assumption of variable knowledge about constant coordination.

\section{b). Second Hypothesis Testing.}

$\mathrm{H} 0: \beta 2=0$ : there is no coordination effect on service quality.

Ha: $\beta 2 \neq 0$ : there is a positive influence of coordination on service quality.

If $\mathrm{t}>\mathrm{t}$ table, then $\mathrm{H} 0$ is rejected and $\mathrm{Ha}$ is accepted. 


\section{a. $\quad$ T test}

Based on the calculation results of SPSS 17 for Window, the tcount obtained was 12,667 and the table with df 148 at $\alpha(0.05)$ was 1,976 . Thus tcount12667> t table1.976 so that $\mathrm{H} 0$ is rejected and Ha is accepted. This shows that coordination has a significant effect on service quality.

b. Determination Analysis

Based on the analysis obtained a coefficient of determination of 0.520 . This shows that $52.0 \%$ of the diversity of coordination is due to the diversity of service quality, while the remaining $48.0 \%$ is caused by other variables.

\section{c. Simple Linear Regression Equation}

Based on the analysis results in testing this hypothesis obtained a simple linear regression equation as follows:

$-\hat{\mathrm{Y}}=\mathrm{a}+\mathrm{b} 2 \mathrm{X} 2$

- $\hat{\mathrm{Y}}=0.925+0.436 \mathrm{X} 2$

This linear regression equation shows that every 1 increase in the value of the coordination variable can increase the value of service quality by 1.361 assuming a constant policy implementation variable.

\section{c). Third Hypothesis Testing}

H0: $\beta 1=\beta 2=0$ : there is no effect of joint policy implementation and coordination on service quality.

Ha: one or both $\beta \neq 0$ : there is a positive influence of policy implementation and coordination together on the quality of service.

If Fcount> Ftable, then $\mathrm{HO}$ is rejected and $\mathrm{Ha}$ is accepted.

\section{a. F test}

Based on the results of SPSS (Statistical Product and Service Solution) 17 calculations for Window, the calculated Fcount value is 152,020 and Ftable with df 147 at $\alpha(0.05)$ is 3,058 . Thus Fcount 152.020> Ftabel3.058, so HO is rejected and Ha is accepted. This shows that the implementation of the policy and coordination together have a significant influence on service quality.

b. Determination Analysis

Based on the analysis obtained a coefficient of determination of 0.674 . This shows that $67.4 \%$ of the diversity of service quality is due to the diversity of policy implementation and coordination, while the remaining $32.6 \%$ is caused by other variables.

c. Multiple Linear Regression Equations

Based on the analysis in testing this hypothesis obtained by the multiple linear regression regression equation as follows:

$-\hat{\mathrm{Y}}=\mathrm{a}+\mathrm{b} 1 \mathrm{X} 1+\mathrm{b} 2 \mathrm{X} 2$

$-\hat{\mathrm{Y}}=0.568+0.275 \mathrm{X} 1+0.287 \mathrm{X} 2$

The definition of double linear equation above is:

- That every 1 increase in the value of the policy implementation variable can improve service quality by 0.843 with an estimated coordination variable constant.

- That every 1 increase in the value of the coordination variable can increase the value of service quality by 0.855 assuming a constant policy implementation variable.

\section{Discussion of Research Results}

The results of data processing are processed using the SPSS 17 for windows program and the following research findings.

\section{Policy Implementation $\left(\mathrm{X}^{\mathbf{1}}\right)$}

Based on the average score of respondents' assessment of each dimension in the Policy Implementation variable $\left(\mathrm{X}^{1}\right)$ it can be described as follows:

\section{Dimension of Purpose}

The average rating of respondents towards the dimension of objectives obtained an average of 4,332. this indicates that the respondent agreed or agreed with the statement submitted. In the objective dimension, the average score of the indicator is the lowest to the highest, namely (1) operational actions, (2) objectives, (3) programs, (4) concrete steps, and (5) implementation.

\section{Dimensions of Obstacles}

The average rating of respondents towards the barrier dimensions was obtained by an average of 4,323. this indicates that the respondent agreed or agreed with the statement submitted. In the obstacle dimension, the average indicator scores are lowest to highest, namely (1) the implementation process, (2) the implementation environment, (3) public organizations, (4) different perceptions, and (5) adequate resources.

\section{Opportunity Dimensions}

The average respondent's assessment of the opportunity dimension was averaged 4,453. this indicates that the respondent agreed or agreed with the statement submitted. In the opportunity dimension, the average indicator score is the lowest to the highest, namely (1) a single policy, (2) according to interests, (3) subject matter, (4) individuals, and (5) researching policies.

\section{Coordination $\left(\mathbf{X}^{2}\right)$}

Based on the average score of respondents' assessment of each dimension in the Coordination variable $\left(\mathrm{X}^{2}\right)$ can be described as follows:

\section{Dimension of Information Transfer}

The average rating of respondents on the dimension of information transfer obtained an average of 4.239. this indicates that the respondent agreed or agreed with the statement submitted. In the dimension of information transfer, the average score of indicators is the lowest to the highest, namely (1) Ideas, (2) Responses, (3) Meanings, (4) Attitudes, and (5) Coordination.

\section{Dimensions of the Communication Process}

The average evaluation of respondents on the dimensions of the communication process obtained an average of 4,203 . this indicates that the respondent agreed or agreed with the statement submitted. In the dimension of the communication process, the average indicator scores the lowest to the highest, namely (1) Ability, (2) Similarity, (3) Meaning, (4) Experience, and (5) Social relations. 


\section{Function Dimensions}

The average rating of respondents on the dimensions of the function obtained an average of 4.295. this indicates that the respondent agreed or agreed with the statement submitted. In the function dimension, the average indicator scores are lowest to highest, namely (1) Alternatives, (2) Influence of sources, (3) Norms, (4) Environment, and (5) Changes in attitude.

\section{Quality of Service (Y)}

Based on the average score of respondents' assessment of each dimension in the variable Service Quality (Y) can be described as follows:

\section{Dimensions of Service Activities}

The average rating of respondents on the dimensions of service activities was obtained by an average of 4,712. this indicates that the respondent agreed or agreed with the statement submitted. In the service activity dimension, the average indicator scores are lowest to highest, namely (1) Procedure, (2) Efficient, (3) Speed, (4) Tasks and functions, and (5) Clarity.

\section{Dimensions of Satisfaction}

The average rating of respondents towards the satisfaction dimension obtained an average of 4,647. this indicates that the respondent agreed or agreed with the statement submitted. In the satisfaction dimension, the average indicator scores are lowest to highest, namely (1) Participatory, (2) Transparency, (3) Conditional, (4) Accountability, and (5) Equality of rights.

\section{Dimensions of service criteria}

The average evaluation of respondents on the dimensions of service criteria obtained an average of 4,647. this indicates that the respondent agreed or agreed with the statement submitted. In the dimensions of service criteria, the average score indicators that are lowest to highest, namely (1) Economical, (2) Simple, (3) Adaptive, (4) Responsive, and (5) Certainty.

Findings and Practical Implications of Research Results

\section{Effect of Policy Implementation on Service Quality}

Based on the results of the analysis of research data that has been done, it has been proven that policy implementation has a positive and real effect on service quality by $51.3 \%$ with dominant indicators namely adequate resources, implementation and researching policies.

\section{Effects of Coordination on Service Quality}

Based on the results of the analysis of research data that has been done, it has been proven that policy implementation has a positive and tangible influence on service quality by $52.0 \%$ with dominant indicators namely social relations, attitude change, and the environment.

\section{Effect of Joint Policy Implementation and Coordination on Service Quality}

Based on the results of the analysis of research data that has been done, it has been proven that policy implementation and coordination together have a positive and tangible influence on the service quality of the Investment Office and the One-Stop Integrated Service by $67.4 \%$, with dominant indicators namely clarity, speed, tasks and function.

\section{CONCLUDING REMARKS}

\section{Conclusion}

The conclusions of this study are:

1. There is a positive and significant effect of policy implementation on the service quality of the Capital Investment Office and the One Stop Integrated Services of DKI Jakarta Province by $51.3 \%$. Where the indicators of the influence of policy implementation on the quality of service are dominant are adequate resources, implementation, and researching policies.

2. There is a positive and significant effect of coordination on the service quality of the Capital Investment and Integrated Services of the One Door Province of DKI Jakarta by $52.0 \%$. Where the indicator of the influence of coordination on the quality of service that is dominant is social relations, attitude changes, and the environment.

3. There is a positive and significant effect of joint policy implementation and coordination on the service quality of the Capital Investment Office and the One Stop Integrated Services of DKI Jakarta Province by $67.4 \%$. Where the influence of policy implementation and coordination together affect the quality of service with dominant indicators being clarity, speed, tasks and functions.

\section{Suggestion}

Some suggestions that can be raised in this study are:

1. An evaluation needs to be carried out by holding a meeting between the DKI Jakarta Provincial Investment and Integrated Services Office of the One Door Agency and other relevant agencies in order to improve the achievement of policy implementation which has been implemented to achieve the targets of a predetermined policy.

2. In order to improve service quality, it is necessary to have inter-agency coordination related to the DKI Jakarta Provincial Investment and Integrated One-Stop Service Agency.

3. Involving the community in providing an assessment of service quality by making programs / applications that can be easily accessed in providing constructive input and suggestions for the DKI Jakarta Provincial Investment and Integrated Services Office.

4. Regular meetings need to be held to discuss the problems that occur in terms of policy implementation and coordination carried out by the DKI Jakarta Provincial Office of the Investment and Integrated Services organization tool so that the best solution can be found in implementing a policy and coordination in order to improve service quality for the community.

\section{REFERENCES}

\section{Book:}

[1] Astrid S. Susanto, 2002, Filsafat Komunikasi, Cetakan I, Penerbit Bina Cipta, Bandung.

[2] Berger \& Chaffee, 2005, Handbook of Communication Science, Beverly Hills, California, Sage. 
[3] Brantakusumah, DS. Riyadi dan Solihin, 2001, Perencanaan Pembangunan Daerah, Jakarta, PT. Gramedia Pustaka Utama.

[4] Dan Nimmo, 2004, Komunikasi Politik, Cetakan Kelima, Penerbit PT. Remaja Rosdakarya, Bandung.

[5] Dror, Yehezkel, 2000, Public Policy-Making Reexamined, San Fransisco: Chandler Publishing Company.

[6] Dwijowijoto, Riant Nugroho. 2004. Kebijakan Publik Formulasi, Implementasi dan Evaluasi. Jakarta : PT Elex Media Komputindo Kelompok Gramedia.

[7] Eri Krisna, 2000, Konsep dan Metode Pelayanan Umum yang Baik, Andi Offset, Yogyakarta.

[8] George and Achilles G. Theodorson, 2000, "Prosses of Communication” Graw-Hill Book Company, Jakarta.

[9] Grindle, Merilee S. 2000. Politics and Policy Implementation in The Third World. USA:Princeton University Press.

[10] Islamy Irfan, M, 2000, Prinsip-prinsip Perumusan Kebijakan Negara, Jakarta : Bumi Aksara.

[11] Jhonson, Kast dan Rosenzweig, 2003, Organization and Management; A System Approach. New York: Mc Gra Hill Bool Company.

[12] Juliantara, Dadang (Ed.), 2005, Peningkatan Kapasitas Pemerintah Daerah Dalam Pelayanan Publik, Pembaruan, Jakarta.

[13] Kansil, 2005, Hukum Tata Pemerintahan Indonesia, Jakarta : Penerbit Bina Aksara.

[14] Kenneth, 2002, "Proses Komunikasi” Geonika Printed, Jakarta.

[15] Koswara, Kertapradja, 2002, Otonomi Daerah, Penerbit Yayasan Pariba, Universitas Satyagama, Jakarta.

[16] 2009, Otonomi Daerah : Untuk Demokrasi \& Kemandirian Rakyat, Jakarta : PT. Candi Cipta Paramuda.

[17] Lukman, 2000, Pengertian Kualitas ,PT. Sumber Ilmu, Jakarta.

[18] Moenir, A.S, 2003. Manajemen Pelayanan Umum di Indonesia, Penerbit Bumi Aksara, Jakarta.

[19] Ndraha, Taliziduhu, 2000, Metodologi Ilmu Pemerintahan, Rineka Cipta, Jakarta.

[20] Nisjar, Karhi, 2001, Teori Sistem dan Pendekatan Sistem Dalam Bidang Manajemen, Bandung: Mandar Maju.

[21] Permata Sari, Achitiya, 2013, Pengaruh Kualitas Jasa Pelayanan, Koordinasi Pegawai, Dan Kemampuan Pegawai Terhadap Kinerja Pelayanan Pada Puskesmas Pakis Di Surabaya. Surabaya.

[22] Rasyid, M.Ryass, 2000, Makna Pemerintahan Tinjauan Dari Segi Etika dan Kepemimpinan Era Globalisasi, CV. Ramadhan, Bandung.

[23] Rusli, Budiman, 2004, Pelayanan Publik di Era Reformasi, www.pikiran-rakyat.com.
[24] Rogers, Everett M., 2003, Communication in Organization, New York: The Free Press.

[25] Rahmulyono, Anjar, 2008, Analisis Pengaruh Kualitas Pelayanan terhadap Kepuasan Pasien Puskesmas Depok I di Sleman. Yogyakarta

[26] Said Zainal, Abidin, 2002, Kebijakan Publik, Cetakan Pertama, Penerbit Yayasan Pancur Siwah.

[27] Scharmm, Wilbur, 2001, The Process and Effects of Mass Communication, Urbana, IL: University of Illinois Press.

[28] Shapere, 2001 "Konsepsi Ilmu Komunikasi”, CV. Arwinan-Print, Jakarta.

[29] Sianipar, 2000, Manajemen Pelayanan Masyarakat, Jakarta: LAN-RI.

[30] Solichin, Abdul Wahab, 2001, Analisis Kebijaksanaan: Dari Formulasi ke Implementasi Kebijaksanaan Negara, Jakarta: Bumi Aksara.

[31] Subarsono. 2005, Analisis Kebijakan Publik: Konsep, Teori, dan Aplikasi. Pustaka Pelajar. Yogyakarta.

[32] Suradinata, Ermaya, 2008, Manajemen Pemerintahan dan Otonomi Daerah, CV. Ramadhan Bandung.

[33] Siregar, Khalid, 2015, Pengaruh Implementasi Kebijakan Terhadap Kualitas Pelayanan Swasembada Beras Di Kabupaten Simeulue. Aceh

[34] Taliziduhu, Ndraha, 2003, Teori Budaya Organisasi, Bumi Aksara, Jakarta.

[35] Triguno, 2000, Kualitas Pegawai, Bumi Aksara, Jakarta.

[36] Widodo, Joko, 2008, Analisis Kebijakan Publik: Konsep dan Aplikasi Analisis Proses Kebijakan Publik, Malang: Bayumedia Publishing.

[37] Winarno, Budi, 2004, Kebijakan Publik: Teori, Proses, dan Studi Kasus Cetakan Kedua. CAPS. Jakarta.

\section{Documents:}

[38] Keputusan Menteri Aparatur Sipil Negara Nomor 81 Tahun 1993 tentang Pedoman Tatalaksana Pelayanan Umum.

[39] Peraturan Daerah Provinsi DKI Jakarta Nomor 12 Tahun 2013 tentang Penyelenggaraan Pelayanan Terpadu Satu Pintu.

[40] Peraturan Gubernur DKI Jakarta Nomor 47 Tahun 2017 tentang Petunjuk Pelaksanaan Pelayanan Terpadu Satu Pintu.

[41] Peraturan Gubernur DKI Jakarta Nomor 281 Tahun 2016 tentang Organisasi Dan Tata Kerja Dinas Penanaman Modal Dan Pelayanan Terpadu Satu Pintu.

[42] Keputusan Kepala Dinas Penanaman Modal Dan Pelayanan Terpadi Satu Pintu Prov. DKI Jakarta Nomor 129 Tahun 2017 tentang Alur Proses Perizinan Di Bidang Ketataruangan, Kajian Lingkungan Dan Pembangunan Untuk Kegiatan Pembangunan. 